\title{
Students' Extracurricular Activities in Higher Education and Its Effect on Personal Development and Academic Achievement (Case Study in Islamic State University of Suska Riau)
}

\author{
Amirah Diniaty ${ }^{1 *}$ \\ Counseling Department, Faculty of Islamic Education and Teacher Training \\ UIN Suska Riau, Indonesia \\ Annisa Kurniati \\ Counseling Department, Faculty of Education and Teacher Training \\ UIN Suska Riau, Indonesia \\ *E-mail: amirah.diniaty@gmail.com \\ DOI:http://dx.doi.org/10.15548/jt.v21i3.96
}

\begin{abstract}
This study investigates the students' extracurricular activities at Islamic State University of Suska Riau concerning the types and forms of their activities, background of the activity, benefits of extracurricular activities, and its effect on students' self-development and academic achievement. 300 students who enroll at sixth semester in eight Faculties (Tarbiyah and Teacher's Training, Sharia and Law, Ushuludin, Dakwah and Communication Sciences, Science and Technology, Psychology, Economics and Social Sciences, Agriculture and Animal Husbandry) were the sample of this study. The data were then processed statistically using percentages and regression of correlation. It was found that the type of extracurricular followed by the students were leadership (70\%), those of whom had the motivation to add insight, knowledge and more critical thinking were $(44.67 \%)$. Some students followed extra-curricular activity because of their solicitation or to follow the main stream (37\%), some students did not get financial benefits from the activity (34.67\%). Some other respondents felt that they could follow the extracurricular talents, interests and personal abilities (58.67\%), and think about their future after graduating from the college $(66 \%)$. Things need to be followed up by students and university staffs were the more active students who attend the extracurricular activities were the lower achievement ones.
\end{abstract}

Keywords: Activity, extracurricular, personal development, academic achievement.

\section{INTRODUCTION}

Students as learners at the college level are a valuable asset of the nation. Harahap (2005) confirms that the student is a moral agent that constitutes the main force in the life of the nation, state and community, more than the other components. Even in the reformation era, students' popularities tend to beat the popularity of other moral enforcer as scholars and teachers. Indeed, after the reform, the students' general concerns had remarkable improvement as an agent of change, the strength of the moral (moral force) and intellectual strength (intellectual force).

In this context, any university or college has a duty to increase the students' knowledge in terms of behavior and methods to critically assess and examine their beliefs, so that what is understood and believed were free of errors (Edward Shils in Nugroho, 1993 ). Therefore, activities in college curricular should not only be in the form of lecture programs (or better known as Semester Credit System). Other activities are co-curricular activities or extra-curricular activities which is valued in terms of co-curricular Credit System (SKK).

Based on Rector of UIN Suska Riau decree no. $259 . \mathrm{a} / \mathrm{R} / 2003$ (in the handbook and information of academic year 2007/2008) the definition of cocurricular or extracurricular activities are activities that support students' curricular activities and is one of the coaching pathway activity of UIN Suska Riau's students. This means that by following extra-curricular activities, students are expected to have a tool for appying the creativity, creations, talents, interests, hobbies and to train their socialization ability to support success in curricular activity. 
Prayitno (2004) suggests that an activity is called extra-curricular activity if it is outside of the planned activities through the course curriculum. Extracurricular activity is a vehicle for students to discover his/her true identity. This was stated by the Directorate of the Ministry of Education college (in http://www.dikti.go.id/Archieve2007/ menudikti.html) that desire for initiative and selfdiscovery grow on a person over the age of students. The age period is also ongoing consolidation process of social development of young adults to becomes social members. As the institutions that protect human life of all members of the academic society, then both process of selfdiscovery for the students and the process of social development into a true citizen should be developed by educational institutions concerned through various development activities.

Prayitno (2004) suggests that extracurricular activities should allow students to take part, more broadly, not just pursue and sink into the lectures, or be a "nerd" who did not move from a paper and pen environment only. Thus the purpose of extracurricular activities for students is to develop student at self outside lectures.

Rector's Decree of UIN Suska Riau No. 259.a/R/2003 (in the handbook and information of academic year 2007/2008) describes that the activities of the credit system of co-curricular or extracurricular should (1) help to achieve the quality of Indonesian human formation (2) develop and improving talent, generate student interest in the Muslim scholars that have scientific work and amaliah knowledge with full responsibility and professionalism (3) help facilitate the learning process of students in support of academic ability (4) appreciate the active role of students in cocurricular / extra-curricular activities (5) develop and enhance the co-curricular activities / extra curricular activities through active observation and regular assessments and (6) provide convenience in assessing and fostering students' co-curricular / extra-curricular activities.

Related to the purpose, the Directorate of Higher National Education (in http://www.dikti.go.id/Archieve

2007/menudikti.html) explains the general purpose of extracurricular activities as to (1) Build a personal student of Pancasila minded, faith and piety to God Almighty, noble character and uphold the noble values of humanity, nationality broadminded, open and capable of deliberation, as well as having high social responsibility (2) Develop human being liberal-minded society that respects the work ethic, discipline, and have a sense of responsibility, tough physical and spiritual, rational and civilized, have initiative and able to lead.

Considering the importance of co-curricular activities / extra curricular for students, State Islamic University of Sultan Syarif Kasim Riau has set guidelines for implementation by the Rector decree No. 259.a/R/ 2003 (Handbook and Academic Information of UIN Suska Riau, 2007). In the first chapter on the general provisions of Article 1 explained that the Credit System Cocurricular (SKK) is a way of giving respect to the co-curricular activities / extra curricular activities for students of UIN Suska Riau. SKK is a unit of credit co-curricular activities in a given period of time which is programmed to meet the requirements in the completion of the study in UIN Suska Riau. Then, it can be one consideration for nomination of scholarships, take charge of intracampus organizations, exemplary predicate and other facilities.

Convening of the credit system activity cocurricular / extracurricular in UIN Suska Riau aims to (1) help to achieve the quality of Indonesian human formation (2) develop and improve their talents, interests of students in generating a knowledgeable Muslim scholars amaliah and work full scientific responsibility and professionalism (3) help facilitate the learning process to support students in their academic abilities (4) appreciate the active role of students in co-curricular activities / extracurricular (5) develop and enhance the cocurricular activities / extra curricular activities through active observation and regular assessments and (6) provide convenience in assessing and fostering student activities that are co-curricular / Extra-curricular.

The Rector of UIN Suska Riau No. 259.a/ $\mathrm{R} / 2003$ (in the handbook and information of academic year 2007/2008) described in chapter 3 that co-curricular activities / Extra curricular is individualized, each student creates or initiative to hold or follow a prescribed activity its aspects as stipulated in article 4 of article 4 the aspects described in extracurricular activities include: aspects of (1) religious and civics of Pancasila (2) reasoning and idealism (3) leadership and loyalty alma mater, the state, nation and religion (4) the fulfillment of the interests and talents of students and (5) community service.

This is in accordance with the realm of student activities organized coaching colleges 
Directorate of the Ministry of Education (in http://www.dikti.go.id/Archives

2007/menudikti.html) namely (1) the development of reasoning, science and expertise, (2) the development of interest and preferences, (3) the development of well-being, (4) development of student organizations, and (5) community activities.

The description or details about the types of activities in each of the following aspects of extracurricular activities (by the Rector of UIN Suska Riau Number 259.a / R / 2003 at the Handbook and Information of Academic Year 2007-2008; 225) are as follows:

\section{Aspects of Religion and Pancasila}

As the mission of the Islamic University, to deepen and develop students' diversity. Thus, in the the extracurricular activities should develop the activities based Pancasila (as Indonesian Ideology). The purpose of the actiivities are to establish a Muslim scholar who fear Allah, has personality and morals in accordance with Pancasila. The forms of activities include: (1) unit of activity (2) assessment forum (3) PHBI / PHBN (4) Places of worship / activities (5) Extension / preaching and sermons (6) Aspects of reasoning and idealism.

\section{Aspects of Scientific and Specialized Expertise}

In the academic community, students reasoning power was developed to examine the nature of symptoms, symptoms of society, and technology in a manner that is commonly used in disciplines from which they graduated. To achieve this higher education, institution should strives to create a culture and climate that supports the development of scientific reasoning power referred to. One way in developing a climate and culture that develops scientific reasoning power among students is organizing extra-curricular activities of scientific and specialized skills for students. In a forum organized by students can understand the kind of scientific discussion and scientific meetings and discussions procedures.

The objective is (1) Instill students with a scientific attitude: cultivate curiosity and penchant studies; increase the power of analysis; build scientific honesty and responsibility; develop openness to different opinions and criticism; enforce an attitude free from prejudice; foster respect for the values, rules and norms; and building orientation to the future; (2) Instilling students with a professional attitude: attitude enforce ethical work; growing desire to always produce work or provide services to a high standard by the profession; build a desire to always improve the capabilities and professional skills; and develop a sense of responsibility for the implementation of the client's work profession and society.

Forms of activity in this aspect includes: scientific discussions, seminars, panel discussions, workshops, symposium, scientific lectures, research, innovative writing competition, speech competition, upgrading/courses, scientific papers, the campus/faculty press, newsletters / magazines, LDK, FKII, PNDK, TARPADNAS, ICI, Suspakin, Suskalak, DIKSAR regiment, Latsar / Hamkamnas, Orientation Cub Scout, Boy Scout Proficient first base, second base Scout advanced, Proficient advanced scouts, Camp.

\section{Aspects of Leadership and Loyalty}

The development of students' reasoning skills, interest, passion, and support to their welfare has been the main purpose of students' organizations. It basically covers the college students in the form of student senate and activity units. In the faculty level, the student senates constitute the members of all disciplines in the emerging departments. The purposes of the senate are: (1) to develop students' organizations in the college environment that supports the implementation of curricular and extra-curricular activities; (2) to support the learning process and the development of reasoning skills, interest, hobby and student welfare services.

Forms of activity in this aspect include: management of SMI, SMF Board, Board of HMJ, Board of MUKOSMA, Scout Executive, Board Force / semester, the Board regiment, student's cooperation Board, Board/Student Activities Committee, Business student dormitories, student clinic Enterprises, inter-campus visits, official visits between regions, between countries official visits, student recreation Enterprises.

\section{The Fulfillment of Students' Talents and Interests}

Undergraduate students aged between 19 and 24 years old in human developmental psychology are relatively young adulthood, and are 
still in the growth rate of both physical and soul. Therefore the form of interest and passion are varied as reflected in the number of units in higher education institutions. Good coaching in the areas of interest and passion, for example in sport, art, writing, scouting and so on, will undoubtedly support their spiritual and physical growth.

The purpose of this activity is to actualize interest and passions and develop their talents to support students' spiritual and physical growth. Forms of student activities on these aspects include (1) sports such as volley ball, badminton, table tennis, Football, Basketball, Pencak Silat, Karate, Judo, Bridge, Swimming, Athletics, Takraw, Nature trail, hike, bike, chess. (2) branches of the arts such as the art of reading the Quran, Qasida, tambourine, marhaban/ litany, band/ vocal group, Folk song, choir, Teather, Jokes, Karawitan, song, dance, calligraphy/ painting, Poetry, Drum band.

\section{Aspects of Community Service}

As part of the younger generation, students must have a social awareness and sensitivity as well as the desire to interact with the community environment. As young citizens, students have the responsibility to comply with the regulations and general provisions. With a view shown above, the students are given the opportunity to actualize their own wide and community activities organized on initiative responsibly.

The purpose of this activity is to actualize the desire and the social sensitivity of students to interact with their environment through community. These activities are initiated and conducted by themselves, which also strengthens mutual communication between the campus and community environment. Further activities in this area include: natural disaster relief efforts, social work students, KKM / Bhakti Armed Forces, SAR / PMI, blood donors, Board of mosque teenage.

The SKK system must be completed prior to final exam (Munaqasyah). Students should have collected 40 scores of SKK for their "mandatory" activities. The problem arises then that, once the student is active in extracurricular activities, they tend forget or ignore curricular activity. Based on a survey, many students who were found to be the so-called activists, rarely attended the class, avoided tasks and they usually got low achievement in academic affairs. Student activists seemed to ignore academic challenge but promoted extracurricular activities.
Related to the research findings, Yunus (2008: 26) states on the application of the academic culture in UIN Suska Riau as follows:

The creation of scientific atmosphere among students in recent times begins to slow down. It is seen from the activities carried out by both students and BEM (faculty students' organization) and HMJ that they were less directed to the scientific discussion of new developments that arose in the community. Most of their activities lead to non-academic activities. Even if there are academic related activities, it is very difficult to attract their attention. However, if the event related to practical matters such as art performances, music concerts, or sport are displayed, then visitors become booming.

It is clear from the above research finding that the activists should also promote their academic achievement since their main task is to learn. So, the preliminary conclusion found many unfavorable impacts of active students in extracurricular activities. This phenomenon is very interesting and therefore, the researcher problematized the issues as follows: (1) What types or forms of extracurricular do the students follow? (2) What are the students' main reasons of choosing the extracurricular activities? (3) What are the benefits of extra-curricular activities for the students? (4) What is the effect of extracurricular activities on the students' personal development? (5) What is the effect of extracurricular activities on students' academic achievement?

This study is expected to be a source of reference for the lecturers and staff to evaluate such a program and to better understand the students' activity in future development of extracurricular program. Moreover, this study serves as reflection for the students to evaluate and develop themselves in various fields.

\section{METHOD}

The type of this study was quantitative research focusing on the response to the present condition related to extracurricular activities in 
UIN Suska Riau and its effect on self-development and achievement of students learning. Data were obtained through the application of a number of data collection techniques and they were analyzed by using descriptive statistical formula (correlation). Narrative analysis was used to provide a thick description of the phenomenon under study.

The main subject of this research was the students in UIN Suska Riau. Thus, the data of this study are generally taken from the students as the primary source, especially students of sixth semester. First to fourth semester students (new students) were not researched with the assumption that they were in the new phase of adjustment to college and have not been active in extracurricular activities. Additionally, the improvement of students' academic performance index of sixth semester can be seen because they have taken some courses for six semesters.

The students as informants were spread in eight faculties (Education and Teacher's Training, Sharia and Law, Ushuludin, Dakwah and Communication Sciences, Science and Technology, Psychology, Economic and Social, Agriculture and Animal Husbandry). Based on recent data of Academic affairs at UIN Riau Suska at academic year 2010, there were 8797 students studying in the sixth semester.

Dealing with the large number of populations, it was necessary to take the sample. Three hundred students from each department in eighth faculties were taken as samples through non-randomized technique.

Data were collected through questionnaires and document analysis. The open questionnaires were in line with Likert scale and documentation was originated from students' Worksheet. The quantitative data were processed through SPSS 16th version and they were analyzed statistically using percentage calculation. In addition, the analysis was in the form of frequency distributions and percentages. They were also used directly for the calculation of correlation analysis between the extracurricular activity of the self-development and learning achievement.

\section{RESEARCH FINDINGS}

Overview of Student Extracurricular Activity in UIN Suska Riau
Only 250 out of 300 questionnaires were completed by the respondents and they are described as follows:

The type of extra-curricular that many students take in the field of leadership was $70 \%$.

Table 1

Type of Extracurricular activities followed by the students (They may choose more than one type)

\begin{tabular}{c|l|c|c}
\hline No & \multicolumn{1}{|c|}{$\begin{array}{c}\text { Name of } \\
\text { Extracurricular }\end{array}$} & F & $\mathbf{\%}$ \\
\hline 1 & Religiosity & 140 & 46,67 \\
\hline 2 & $\begin{array}{l}\text { Reasoning and } \\
\text { idealism }\end{array}$ & 175 & 58,33 \\
\hline 3 & Leadership & 210 & 70 \\
\hline 4 & Talent and Art & 102 & 34 \\
\hline
\end{tabular}

\section{Time Allotments to Participate in Extra- curricular activities.}

The table reveals that students participating in extracurricular activities began in the first half $(44.33 \%)$, but there is also a new take on the term $\mathrm{V}(3 \%)$. Apparently there are $3.67 \%$ of students who took part in the emerging extracurricular lectures, and they tend to join extracurricular activities rather than lectures.

Table 2

Time Allotments to Participate in Extracurricular Activities

\begin{tabular}{|c|c|c|c|c|c|}
\hline \multirow{2}{*}{ No } & \multirow{2}{*}{$\begin{array}{l}\text { State } \\
\text { ment }\end{array}$} & \multirow{2}{*}{\multicolumn{2}{|c|}{$\begin{array}{c}\text { Alternative of } \\
\text { Answer }\end{array}$}} & \multicolumn{2}{|c|}{ Amount } \\
\hline & & & & $\mathbf{f}$ & $\%$ \\
\hline \multirow{5}{*}{1} & \multirow{5}{*}{$\begin{array}{l}\text { Begins } \\
\text { to } \\
\text { follow } \\
\text { extrac } \\
\text { urricul } \\
\text { ar } \\
\text { activiti } \\
\text { es in }\end{array}$} & a. & First semester & 133 & 44,33 \\
\hline & & b. & $\begin{array}{l}\text { Second } \\
\text { semester }\end{array}$ & 57 & 19,00 \\
\hline & & c. & Third semester & 30 & 10,00 \\
\hline & & d. & Fourth semester & 21 & 7,00 \\
\hline & & e. & Fifth semester & 9 & 3,00 \\
\hline \multirow{3}{*}{2} & \multirow{3}{*}{$\begin{array}{l}\text { Time } \\
\text { used } \\
\text { to } \\
\text { follow } \\
\text { more } \\
\text { extra- } \\
\text { curric } \\
\text { ular }\end{array}$} & a. & College Holiday & 42 & 14,00 \\
\hline & & b. & $\begin{array}{l}\text { When there is } \\
\text { No class }\end{array}$ & 72 & 24,00 \\
\hline & & c. & $\begin{array}{l}\text { After course } \\
\text { completion, } \\
\text { although the } \\
\text { extracurricular }\end{array}$ & 112 & 37,33 \\
\hline
\end{tabular}




\begin{tabular}{|l|l|l|l|l}
$\begin{array}{l}\text { activi- } \\
\text { ties }\end{array}$ & d. $\begin{array}{l}\text { activities have } \\
\text { taken place } \\
\text { before }\end{array}$ & $\begin{array}{l}\text { In learning time } \\
\text { and often have } \\
\text { to leave the } \\
\text { course meeting }\end{array}$ & 13 & 4,33 \\
\cline { 2 - 4 } & e. $\begin{array}{l}\text { During the class } \\
\text { sessions, but } \\
\text { prefers to join } \\
\text { extracurricular } \\
\text { activities rather } \\
\text { than lectures }\end{array}$ & 11 & 3,67 \\
\hline
\end{tabular}

The level of activity of students in the following extracurricular activities which revealed $55.33 \%$ said their participation was not scheduled and $11.33 \%$ said activity followed extracurricular 3 times a month.

Table 3

The level of students' activity in the following extracurricular activities

\begin{tabular}{|c|l|c|c}
\hline \multirow{2}{*}{ No } & \multirow{2}{*}{ Participation Intensity } & \multicolumn{2}{|c}{ Amount } \\
\cline { 3 - 4 } & & $\mathrm{f}$ & $\%$ \\
\hline 1 & Once month & 96 & 32.00 \\
2 & Twice a month & 37 & 12.33 \\
3 & Three times month & 34 & 11.33 \\
4 & Four times a month & 52 & 17.33 \\
5 & Unscheduled & 166 & 55.33 \\
6 & Others & 22 & 7.33 \\
\hline
\end{tabular}

Then it was revealed only $21 \%$ of the respondents were always active in extracurricular activities. Precisely $32.33 \%$ of them left the program. It can be seen in the table 4 below:
Table 4

Students' Activeness to Follow Extracurricular Activities

\begin{tabular}{|l|l|c|c|c|}
\hline \multirow{2}{*}{ No } & \multirow{2}{*}{ Activeness } & \multicolumn{2}{|c|}{ Amount } & \multirow{2}{*}{ Total } \\
\cline { 3 - 4 } & & F & $\%$ & \\
\hline 1 & Always active & 63 & 21.00 & \\
2 & Active & 31 & 10.33 & \\
3 & Less active & 59 & 19.67 & \\
4 & Not active & 97 & 32.33 & \\
\hline
\end{tabular}

Description:

1. is always active: the intensity of participation is always active $+2-4 \times$ / month

2. active: always active participation + intensity 1-3 x/ month

3. less active: sometimes active $+1-2 \times /$ month

4. not active: rarely / not active $+1 \mathrm{x} /$ month and not scheduled

\section{The Reason for Students to Choose Extra- curricular Activities}

The result apparently wants to add insight, knowledge and a more critical way of thinking is the reason most $(44.67 \%)$ students attend extracurricular activities. In addition, there are (4\%) who argued for just this spare time after college.

Table 5

Background / Reasons to Choose Extracurricular Activities

\begin{tabular}{|c|c|c|c|c|c|c|}
\hline \multirow{2}{*}{ No } & \multirow{2}{*}{$\begin{array}{l}\text { State- } \\
\text { ment }\end{array}$} & \multirow{2}{*}{\multicolumn{2}{|c|}{$\begin{array}{c}\text { Alternative } \\
\text { Answers }\end{array}$}} & \multicolumn{2}{|c|}{ Total } & \multirow{2}{*}{ Tot. } \\
\hline & & & & $\mathbf{F}$ & $\%$ & \\
\hline \multirow{2}{*}{1} & $\begin{array}{l}\text { The } \\
\text { main } \\
\text { reason } \\
\text { for } \\
\text { choosin }\end{array}$ & a. & $\begin{array}{l}\text { add insight } \\
\text { knowledge } \\
\text { and critical } \\
\text { thinking } \\
\text { over. }\end{array}$ & 134 & 44.67 & \multirow{2}{*}{250} \\
\hline & $\begin{array}{l}\mathrm{g} \text { and } \\
\text { followin } \\
\mathrm{g} \\
\text { extracur } \\
\text { ricular }\end{array}$ & b. & $\begin{array}{l}\text { directing } \\
\text { potential, } \\
\text { talents } \\
\text { and } \\
\text { interests }\end{array}$ & 68 & 22.67 & \\
\hline
\end{tabular}




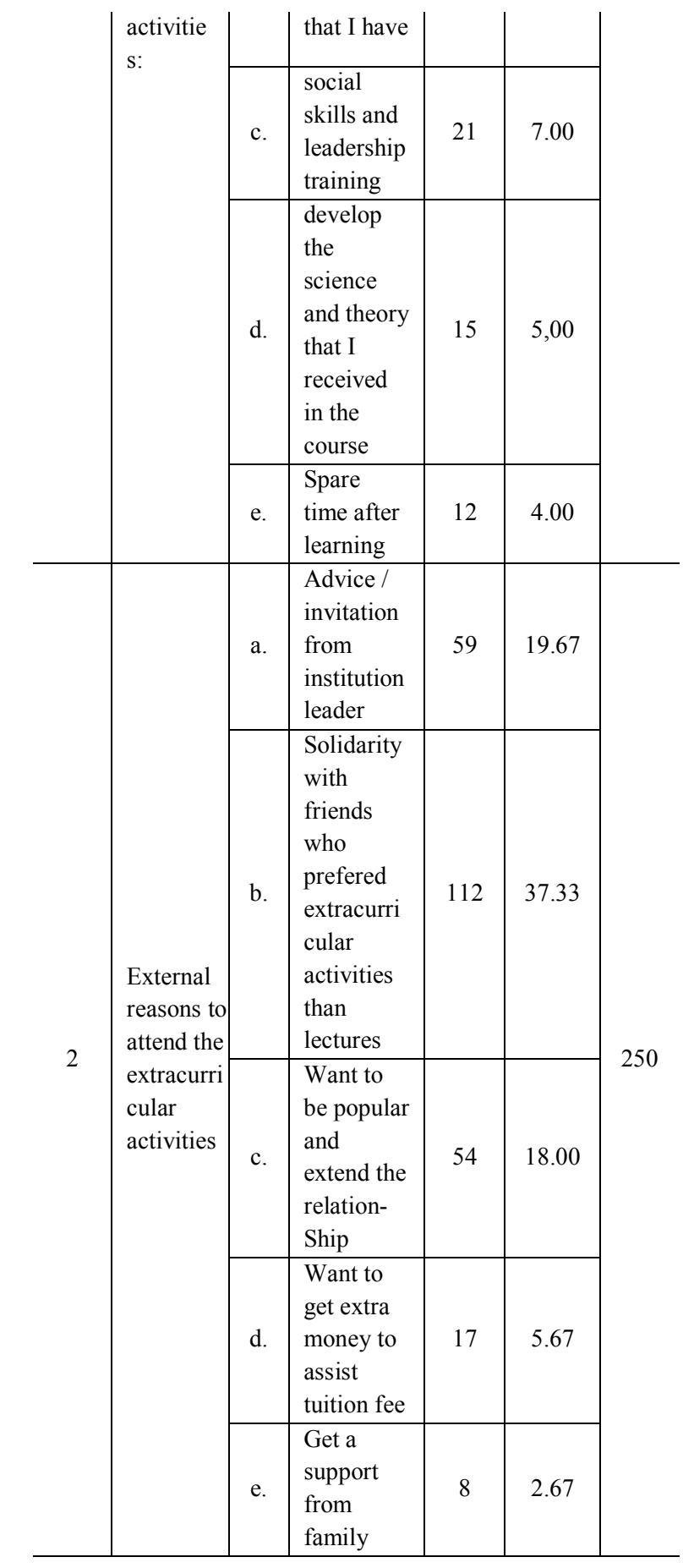

The Advantages or Benefits for Students to Attend Extra-curricular Activities

Revealed that $39 \%$ of students feel the insight, knowledge, and ways berpkir become sharper and critical as the main advantage that nonmaterial nature of the following extracurricular activities. Only 4\% who felt the support of extracurricular activities, especially academic understanding of the lecture material. Instead the students as much as $34.67 \%$ expressed no material benefit from following extracurricular activities. $33.67 \%$ of students felt that the extracurricular activities are less related to the study program followed and there is even $3.67 \%$ of students just do not know what exactly competency to be achieved from the study programs / majors so much interested to participate in extracurricular rather than lecture.

Table 6

\section{Students' Advantages / Benefits in Extra- Curricular Activities}

\begin{tabular}{|c|c|c|c|c|c|c|}
\hline \multirow{2}{*}{ No } & \multirow{2}{*}{$\begin{array}{l}\text { State- } \\
\text { ment }\end{array}$} & \multirow{2}{*}{\multicolumn{2}{|c|}{$\begin{array}{c}\text { Alternative of } \\
\text { Answer }\end{array}$}} & \multicolumn{2}{|c|}{ Amount } & \multirow{2}{*}{$\begin{array}{l}\text { Tot } \\
\text { al }\end{array}$} \\
\hline & & & & $\mathbf{F}$ & $\%$ & \\
\hline \multirow{5}{*}{1} & \multirow{5}{*}{$\begin{array}{l}\text { The main } \\
\text { non- } \\
\text { material } \\
\text { advantage. }\end{array}$} & a. & $\begin{array}{l}\text { satisfaction for } \\
\text { the } \\
\text { achievements } \\
\text { gained from } \\
\text { actualizing } \\
\text { talent, own } \\
\text { potencies }\end{array}$ & 55 & 18.33 & \multirow{5}{*}{250} \\
\hline & & b. & $\begin{array}{l}\text { popularity and } \\
\text { wide } \\
\text { relationship } \\
\text { with no age } \\
\text { restrictions } \\
\text { and positions }\end{array}$ & 37 & 12.33 & \\
\hline & & c. & $\begin{array}{l}\text { insight, } \\
\text { knowledge } \\
\text { and way of } \\
\text { thinking } \\
\text { becomes } \\
\text { sharper and } \\
\text { the critical }\end{array}$ & 117 & 39.00 & \\
\hline & & d. & $\begin{array}{l}\text { Trained to be } \\
\text { leader in } \\
\text { organizing an } \\
\text { activity }\end{array}$ & 29 & 9.67 & \\
\hline & & e. & $\begin{array}{l}\text { To support } \\
\text { academic } \\
\text { especially } \\
\text { understanding } \\
\text { on course } \\
\text { materials }\end{array}$ & 12 & 4.00 & \\
\hline \multirow[b]{2}{*}{2} & \multirow{2}{*}{$\begin{array}{l}\text { The } \\
\text { laterial } \\
\text { dvantage to } \\
\text { ttend } \\
\text { xtracurricul } \\
\text { r activity }\end{array}$} & a. & $\begin{array}{l}\text { To get extra } \\
\text { money to pay } \\
\text { tuition fees }\end{array}$ & 49 & 16.33 & \multirow[b]{2}{*}{250} \\
\hline & & b. & $\begin{array}{l}\text { have facilities } \\
\text { such as a } \\
\text { vehicle, plane } \\
\text { tickets to go } \\
\text { outside easily }\end{array}$ & 16 & 5.33 & \\
\hline
\end{tabular}




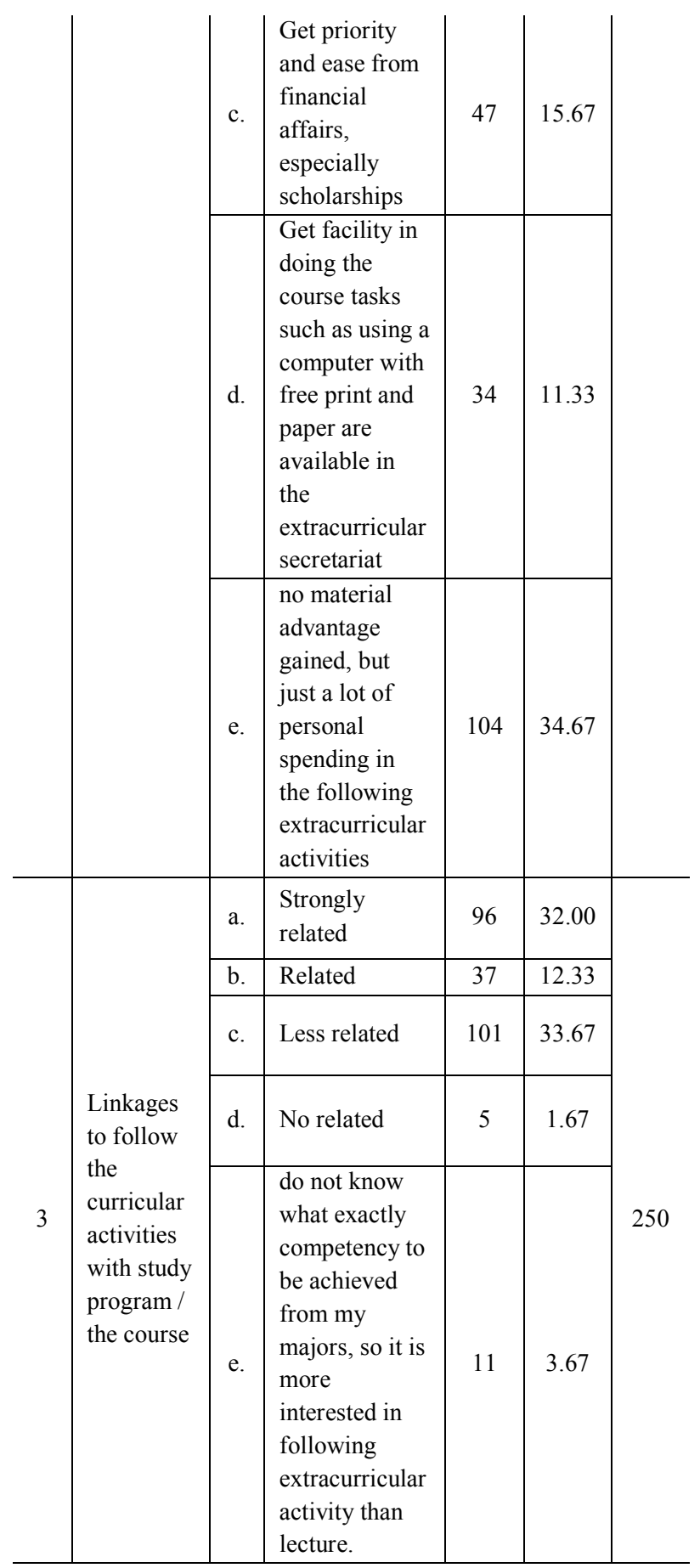

The Influence of Extracurricular Activities on Students' Personal Development

Table 8 shows the participation intensity in following extracurricular activities:
Table 7

Participation Intensity

\begin{tabular}{l|l}
\hline No & \multicolumn{1}{|c}{ Participation Intensity } \\
& \\
\hline 1 & $1 \times$ in a month \\
2 & $2 \times$ in a month \\
3 & $3 \times$ in a month \\
4 & $4 \times$ in a month \\
5 & Unscheduled \\
6 & Others \\
\hline
\end{tabular}

\section{Students' Activities to Follow Extracurricular Activities}

The data revealed that $55.33 \%$ of students acknowledged that their participation was not scheduled and $11.33 \%$ said activity followed extracurricular three times a month. It seen in table 5 .

Table 8

The Level of Students' Activities in the Following Extra-curricular Activities

\begin{tabular}{c|c}
\hline \multicolumn{2}{c}{ Amount } \\
\hline $\mathrm{f}$ & $\%$ \\
\hline 96 & 32.00 \\
37 & 12.33 \\
34 & 11.33 \\
52 & 17.33 \\
166 & 55.33 \\
22 & 7.33 \\
\hline
\end{tabular}

It was also revealed that there were only $21 \%$ of students were active in extracurricular activities. Meanwhile, there were precisely $32.33 \%$ of students who were no longer active.

Table 9

Students' Activeness to Follow Extracurricular Activities

\begin{tabular}{l|l|c|c|c}
\hline \multirow{2}{*}{ No } & \multirow{2}{*}{ Activeness } & \multicolumn{2}{|c|}{ Amount } & \multirow{2}{*}{ Total } \\
\cline { 3 - 4 } & & F & \% & \\
\hline 1 & Always active & 63 & 21.00 & \\
2 & Active & 31 & 10.33 & \multirow{2}{*}{250} \\
3 & Less active & 59 & 19.67 & \\
4 & Not active & 97 & 32.33 & \\
\hline
\end{tabular}


The description of the table above are:

1. The intensity of participation is always active $+2-4 \mathrm{x} /$ month

2. Active: always active participation + intensity $1-3 \mathrm{x} /$ month

3. Less active: sometimes active $+1-2 \times /$ month

4. Not active: rarely / not active $+1 \mathrm{x} /$ month and not scheduled

The Influence of Extra-curricular Activities on Students' Talents, Interests and Personal Abilities

The findings can seen in the following table:

Table 10

The Influence of Extra-curricular Activities on Students' Talents, Interests and Personal Abilities

\begin{tabular}{|c|c|c|c|c|c|c|c|c|}
\hline \multirow{3}{*}{ No } & \multirow{3}{*}{ Statement } & \multicolumn{6}{|c|}{ Answer } & \multirow{3}{*}{$\begin{array}{l}\text { To } \\
\text { tal }\end{array}$} \\
\hline & & \multicolumn{2}{|c|}{ Yes } & \multicolumn{2}{|c|}{ No } & \multicolumn{2}{|c|}{$\begin{array}{c}\text { Uncer } \\
\text { tain }\end{array}$} & \\
\hline & & $\mathbf{F}$ & $\%$ & $\mathbf{F}$ & $\%$ & f & $\%$ & \\
\hline 1 & $\begin{array}{l}\text { Extracurric } \\
\text { ular } \\
\text { activities } \\
\text { followed } \\
\text { can } \\
\text { support the } \\
\text { talents in } \\
\text { order to get } \\
\text { achieveme } \\
\text { nts }\end{array}$ & $\begin{array}{c}13 \\
7\end{array}$ & $\begin{array}{c}45.6 \\
7\end{array}$ & 49 & $\begin{array}{l}16 . \\
33\end{array}$ & $\begin{array}{l}6 \\
4\end{array}$ & $\begin{array}{c}21.3 \\
3\end{array}$ & 250 \\
\hline 2 & $\begin{array}{l}\text { Extracurric } \\
\text { ular } \\
\text { activity } \\
\text { focused is } \\
\text { really } \\
\text { suitable } \\
\text { with the } \\
\text { interest }\end{array}$ & $\begin{array}{c}15 \\
4\end{array}$ & $\begin{array}{c}51.3 \\
3\end{array}$ & 35 & $\begin{array}{l}11 . \\
67\end{array}$ & $\begin{array}{l}6 \\
1\end{array}$ & $\begin{array}{c}20 \\
33\end{array}$ & 250 \\
\hline 3 & $\begin{array}{l}\text { No talent } \\
\text { developme } \\
\text { nt from } \\
\text { extracurric } \\
\text { ular } \\
\text { activities } \\
\text { followed }\end{array}$ & 48 & $\begin{array}{c}16,0 \\
0\end{array}$ & $\begin{array}{c}16 \\
4\end{array}$ & $\begin{array}{c}54 \\
67\end{array}$ & $\begin{array}{l}3 \\
8\end{array}$ & $\begin{array}{c}12,6 \\
7\end{array}$ & 250 \\
\hline 4 & $\begin{array}{l}\text { Personal } \\
\text { skills } \\
\text { improved } \\
\text { in life and } \\
\text { more }\end{array}$ & $\begin{array}{c}15 \\
3\end{array}$ & $\begin{array}{c}51,0 \\
0\end{array}$ & 35 & $\begin{array}{c}11 \\
67\end{array}$ & $\begin{array}{l}6 \\
2\end{array}$ & $\begin{array}{c}20,6 \\
7\end{array}$ & 250 \\
\hline
\end{tabular}

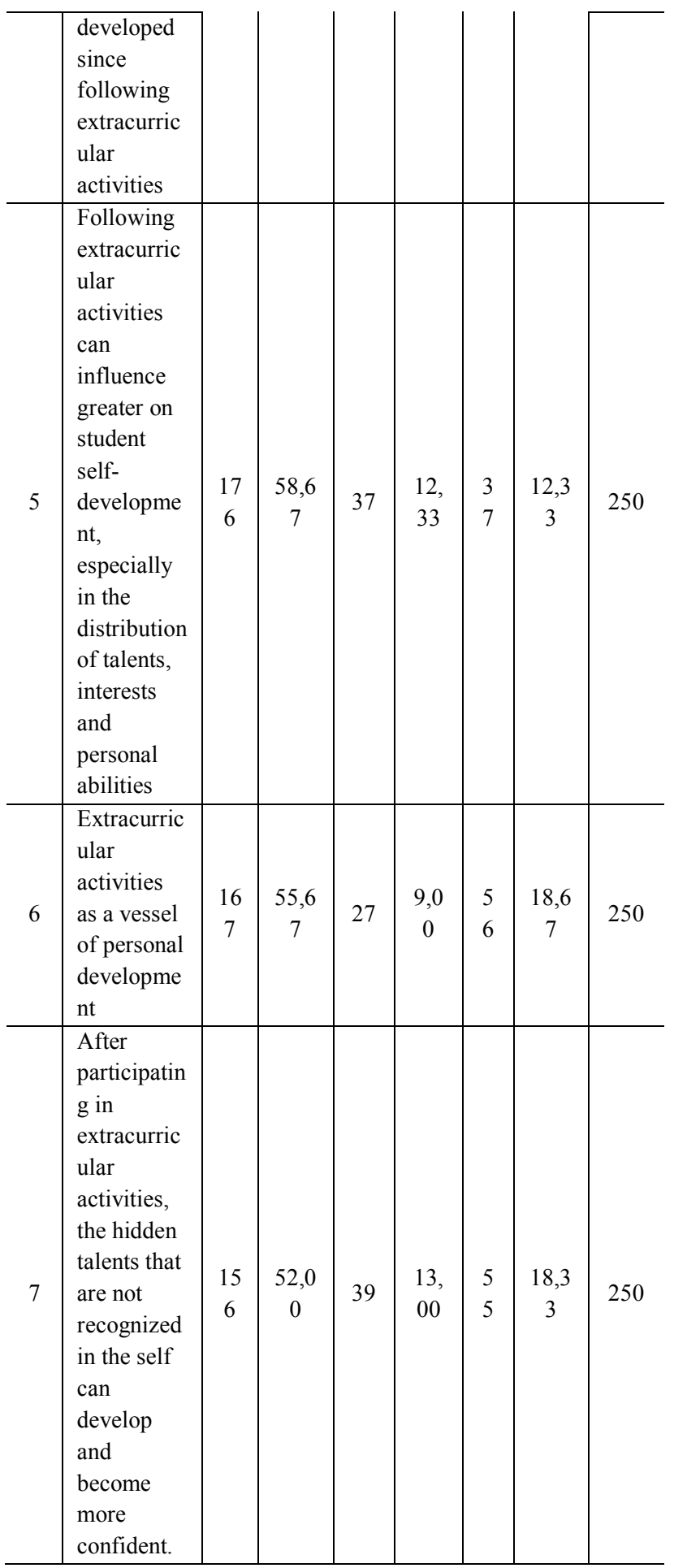


Active Effect of Extracurricular Activities on Student's Academic Achievement

To see the students' academic achievement during the extracurricular activities, the students were asked to write index of academic achievement each semester to semester V. Then the researchers classified academically as seen from the value / GPA each semester as follows:

Table 11

Students' Academic Achievement While Attending Extracurricular Activities

\begin{tabular}{l|l|c|c|c}
\hline \multirow{2}{*}{ No } & \multirow{2}{*}{ Score } & \multicolumn{2}{|c|}{ Numbers } & \multirow{2}{*}{ total } \\
\cline { 3 - 4 } & & $\mathbf{F}$ & $\%$ & \\
\hline 1 & Increase & 86 & 28.67 & \\
2 & Stabile & 112 & 37.33 & \multirow{2}{*}{250} \\
3 & Decline & 52 & 17.33 & \\
\hline
\end{tabular}

Being active in extracurricular activities can influence students' academic achievement. These data were processed using SPSS 16 by contingency correlation, the result is as described below:

Table 12

Active Effects in Extracurricular Activities on Students' Academic Achievement with SPSS 16 Case Processing Summary

\begin{tabular}{|c|c|c|c|c|c|c|}
\hline & \multicolumn{6}{|c|}{ Cases } \\
\hline & \multicolumn{2}{|c|}{ Valid } & \multicolumn{2}{|c|}{ Missing } & \multicolumn{2}{|c|}{ Total } \\
\hline & $\mathrm{N}$ & Percent & $\mathrm{N}$ & $\begin{array}{c}\text { Perc } \\
\text { ent }\end{array}$ & $\mathrm{N}$ & $\begin{array}{c}\text { Perc } \\
\text { ent }\end{array}$ \\
\hline $\begin{array}{l}\text { Students' } \\
\text { Actieveness in } \\
\text { Extracurricular } \\
\text { Activities * } \\
\text { Classification of } \\
\text { Students' } \\
\text { Academic } \\
\text { Achievement }\end{array}$ & 250 & $100.0 \%$ & 0 & $.0 \%$ & 250 & $\begin{array}{r}100 . \\
0 \%\end{array}$ \\
\hline
\end{tabular}

\section{Correlations}

\begin{tabular}{|c|c|c|c|}
\hline & & $\begin{array}{l}\text { Activeness } \\
\text { of Students } \\
\text { in } \\
\text { Extracurric } \\
\text { ular } \\
\text { Activities }\end{array}$ & $\begin{array}{c}\text { Classificatio } \\
\text { n of } \\
\text { Students' } \\
\text { Academic } \\
\text { Achievement }\end{array}$ \\
\hline \multirow{3}{*}{$\begin{array}{l}\text { Activeness } \\
\text { of Students } \\
\text { in } \\
\text { Extracurricul } \\
\text { ar Activities }\end{array}$} & $\begin{array}{l}\text { Pearson } \\
\text { Correlati } \\
\text { on }\end{array}$ & 1 & $-.418(* *)$ \\
\hline & $\begin{array}{l}\text { Sig. (2- } \\
\text { tailed) }\end{array}$ & & .000 \\
\hline & $\mathrm{N}$ & 250 & 250 \\
\hline \multirow{3}{*}{$\begin{array}{l}\text { Classificatio } \\
\text { n of } \\
\text { Students' } \\
\text { Academic } \\
\text { Achievement }\end{array}$} & $\begin{array}{l}\text { Pearson } \\
\text { Correlati } \\
\text { on }\end{array}$ & $-.418(* *)$ & 1 \\
\hline & $\begin{array}{l}\text { Sig. (2- } \\
\text { tailed) }\end{array}$ & .000 & \\
\hline & $\mathrm{N}$ & 250 & 250 \\
\hline
\end{tabular}

\section{Crosstabulation}

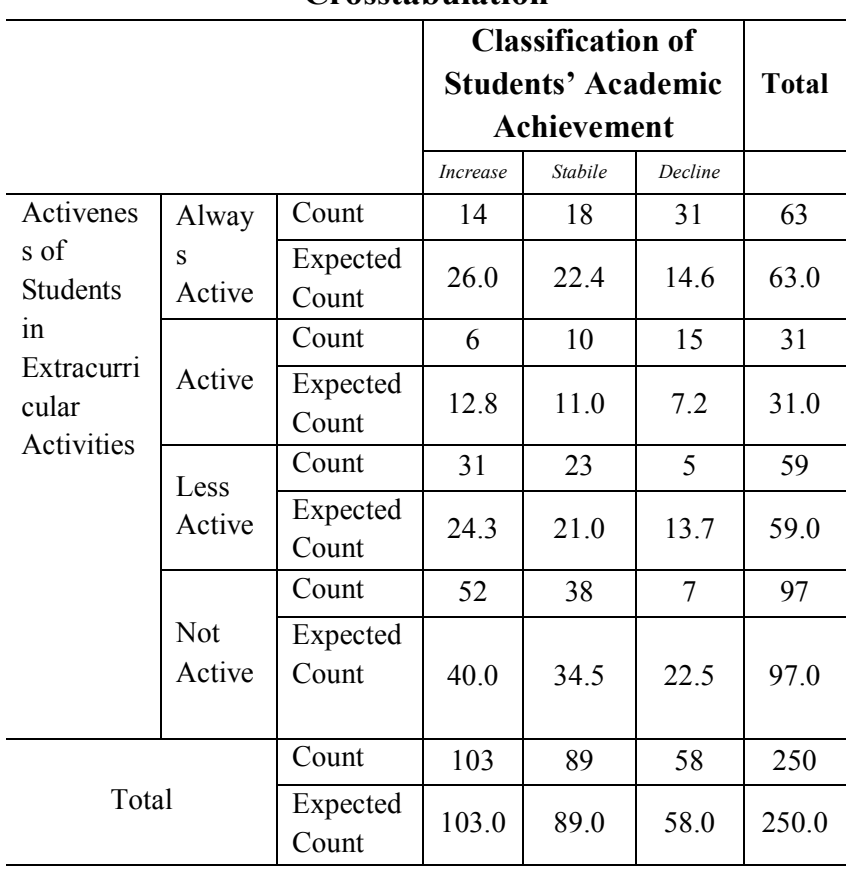


Chi-Square Tests

\begin{tabular}{c|c|c|c}
\hline & & df & $\begin{array}{c}\text { Asymp. } \\
\text { Sig. (2- } \\
\text { sided) }\end{array}$ \\
\hline $\begin{array}{c}\text { Pearson Chi- } \\
\text { Square }\end{array}$ & $59.113(\mathrm{a})$ & 6 & .000 \\
\hline Likelihood Ratio & 59.914 & 6 & .000 \\
\hline $\begin{array}{c}\text { Linear-by-Linear } \\
\text { Association }\end{array}$ & 43.481 & 1 & .000 \\
\hline N of Valid Cases & 250 & & \\
\hline
\end{tabular}

0 cells $(.0 \%)$ have expected count less than 5 . The minimum expected count is 7.19 .

\begin{tabular}{l|l|r|r}
\multicolumn{2}{l}{ Symmetric Measures } \\
\hline \multicolumn{2}{l}{} & Value & $\begin{array}{c}\text { Approx. } \\
\text { Sig. }\end{array}$ \\
\hline $\begin{array}{l}\text { Nominal } \\
\text { by }\end{array}$ & $\begin{array}{l}\text { Contingency } \\
\text { Coefficient }\end{array}$ & .437 & .000 \\
Nominal & N of Valid Cases & 250 & \\
\hline
\end{tabular}

a. Not assuming the null hypothesis.

b. Using the asymptotic standard error assuming the null hypothesis.

\section{DISCUSSION}

Data that have been processed from 250 students (130 males and 120 females), were obtained from the distribution of questionnaire. Most students who followed extracurricular activities since the first semester were 133 respondents (44.33\%). Most students of UIN Suska Riau followed the kind of extracurricular activities in the field of leadership (70\%). But the form of extracurricular activity that is mostly followed was seminars with reasoning and idealism types of activities (70.33\%). This is possible since seminars was not tied with time and therefore it can be followed at any time. While the least desirable activities was scouts II and judo. These data were consistent with the questionnaire that a large percentage of both $0 \%$.

The reason of the majority of respondents $(44.67 \%)$ to chose extracurricular and other activities depends on themselves because they wanted to add to the insight, knowledge and way of more critical thinking. While the reason to follow extracurricular for the majority $(37.33 \%)$ of respondents is because they called to follow it. Eventhough following extracurricular activities did not give financial advantage. As $34.67 \%$ or 104 respondents replied "there is no financial advantage I got, even I spent a lot of extra expenditures to follow the extracurricular activities".

Extracurricular activities are very influential to the distribution of talent, personal interests and abilities of students. Over half of the respondents $(58.67 \%)$ who said that the following extracurricular activities largely influenced the personal development of students, especially in the distribution of talents, and interests and personal abilities. Over $70.33 \%$ said the following extracurricular activities had a positive influence in the development of self as a student who will jump in and get along with the wider community. It turns out that extracurricular activities do not interfere with the activity of the lectures because most students attend extracurricular after completion of the course, although the extracurricular activities that had gone before. Only $3.67 \%$ of respondents who followed extracurricular during class time, and prefers join extracurricular activities rather than lectures.

Salient or major influence in extracurricular activities on students' academic achievement were processed using SPSS 16. This is also analyzed by the correlation of 
contingency, the results can be seen in Table 4.6. Hypothesis testing that there was a significant positive correlation between the level of activity of students in extracurricular activities with students' academic achievement (Ho) is explaine through the following interpretation:

1. In the table 4.6. Correlations magnitude of the correlation coefficient was -0.418 . It indicates the direction of the negative correlation.

2. From Table 2 Correlations also known probability 0.000 magnitude was smaller than 0.05 then Ho is rejected. This means that there is no significant positive correlation between the activity in the extracurricular activities of the students' academic achievement.

3. Two asterisks in Table 4.6. Correlations showed no significant correlation at alpha 0.01 .

4. On the Symmetric Measures table, the magnitude of the correlation coefficient is 0.437 contingensi. While the level of probability that is 0,000 less than 0.05 . Thus Ho is rejected.

Thus, the hypothesis Ha was accepted and Ho was rejected. The conclusion was that there was a significant negative correlation between the level of activity of students in extracurricular activities with students' academic achievement in UIN Suska Riau. That is, the higher the level of activity of students in extracurricular is followed by the declining of academic performance of students. Conversely, the lower the activity of the students in the following extracurricular increases students' academic achievement, as seen in the histogram below:

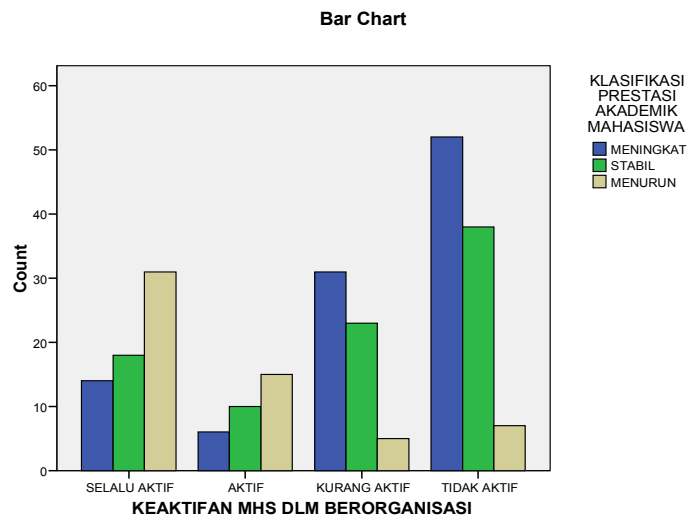

\section{RECOMMENDATIONS}

It is recommended that students should choose the type of extracurricular activities in the areas of reasoning and idealism like competition of innovative work, papers and other things that can support academic skills apart from other types of extracurricular activities. It should support the extracurricular activities-curricular activities / competencies of actual study program. Extracurricular activities are expected to be a means for students to explore the lecture material and add soft skillnya. Beside, it is recommended that students choose extracurricular activities according to their talents, interests and academic abilities, not based on the invitation of friends.

Following negative correlation with academic achievement extracurricular activities need to be a record for students and academic advisors and stakeholders in higher education. These findings indicated that the student's participation in extracurricular activities was not in accordance with the expected goals. For the active role of the academic advisor, chairman of the faculty and the university level student needs to review the implementation of the work program and extracurricular activities that students followed. Further studies are qualitative or 
case study can be done to find the root causes declining academic performance of students who actively participated in extracurricular.

\section{REFERENCES}

Direktorat Perguruan Tinggi Diknas (dalam http://www.dikti.go.id/Archieve 2007/ menudikti.html. Peningkatan Mutu Pembinaan Kemahasiswaan.

Harahap, S. (2005). Penegakan Moral Akademik di dalam dan diluar kampus. Jakarta: PT. RajaGrafindo Persada.

Hadi, S. (1989). Metodologi Reseach. Jakarta. Andi Offset.

Nugroho, A. A. (1993). The Academic Ethics" (terjemahan ke bahasa Indonesia). Jakarta: Yayasan Obor Indonesia.

Prayitno. (2004). Pengembangan Potensi Mahasiswa. Padang: UNP

Satgasus 3SCPD. (1997). Seri Latihan Keterampilan Belajar: Program Studi dan Beban Studi. Jakarta: PGSM Dikti Depdikbud.

UIN Suska Riau. (2007). Buku Panduan dan Informasi Akademik Tahun Akademik 2007/2008.

UIN Suska Riau. (2009). Buku Panduan dan Informasi Akademik Tahun Akademik 2009/2010.

Yunus, M. (2008). Laporan Penelitian :Penerapan Budaya akademik di UIN Suska Riau. Lembaga Penelitian dan Pengembangan UIN Suska Riau. 